\title{
TYPE SPECIFIC MENINGOCOCCIC AGGLUTININS. III. APPLICA- TION OF THE TEST TO SPORADIC CASES AND TO CLINICALLY TYPICAL CASES LACKING BACTERIOLOGICAL PROOF ${ }^{1}$
}

\author{
By CAROLYN R. FALK AND EMANUEL APPELBAUM
}

(From the Bureau of Laboratories, Department of Health, City of New York, N. Y.)

(Submitted for publication August 29, 1952; accepted October 8, 1952)

\section{INTRODUCTION}

The type specific meningococcic agglutinin content of human serums has been under investigation since March 1942 at the Bureau of Laboratories of the Department of Health of the City of New York. The first paper of this series was published in 1944 (1) in which the method of testing was described in detail and certain limitations of the test were discussed. The second report in 1945 (2) showed the relationship of the titers to the course of the disease. It was shown that meningococcic agglutinin production followed the classical curve of the other febrile diseases. Particular emphasis was placed on a study of bacteriologically proved cases. The observations were made at a time when the incidence of meningococcic infection due to Group 1 was comparatively high. It was, therefore, considered important to determine whether this test would have equal value if used on sporadic cases when the infecting organisms might be less antigenic and under all other conditions of a long range study. Continuation of the investigation was further stimulated by the fact that the cultural methods usually employed to detect the etiological agent were often unsuccessful following sulfonamide and antibiotic therapy.

\section{METHOD}

The method used in this study has been described in our previous papers $(1,2)$. Briefly, all serums were tested for Group 1, Group 2-alpha, and Group 2 agglutinins. The cultures used for the antigens were standard stock strain cultures of well established specificity and antigenicity. Serum dilutions ranged from $1 / 50$ to $1 / 1,600$. Each dilution was increased twofold. The tests were incubated at $37^{\circ} \mathrm{C}$. for 2 hours, centrifuged at high speed for ten minutes and kept in the refrigerator overnight. Readings were made after centrifugation and also following overnight storage. The last tube showing definite ( 2 plus) clumping was considered indicative of

1 Presented at the Fifty-second General Meeting of the Society of American Bacteriologists, May 29, 1952. the titer of the serum. Agglutinin titers over 1/100 were regarded as significant of the presence of specific antibody, whereas those up to and including 1/100 were considered within the normal range.

\section{MATERIALS}

Since March 1942, 4,272 serums collected from 2,826 individuals have been tested for type specific meningococcic agglutinin content. ${ }^{2}$ The sources of these specimens were 407 cases of bacteriologically proved meningococcic infection, 1,269 cases of suspected meningococcic infection, 211 individuals suffering from gonococcic infection, 77 instances of exposure to active meningococcic infection, 387 cases of febrile diseases caused by organisms other than the meningococcus, and as controls 465 serums sent to the laboratory for routine syphilis serology.

\section{RESULTS}

The distribution of meningococcic agglutinins among the various groups of subjects studied during the ten year period followed essentially the same pattern observed in the initial three year investigation (Table I). It should be noted that results included in this table represent individuals tested one or more times. Significant titers were observed in 72.9 per cent of the 407 bacteriologically proved cases of meningococcic infection. The 1,269 cases of suspected meningococcic infection were placed in two groups. The first group consisted of 133 instances in which clinical symptoms were typical but bacteriological confirmation was lacking. Significant agglutinins were observed in 81.2 per cent of these cases. The second group of 1,136 cases included those with doubtful clinical diagnosis. Only 47 per cent of these cases showed agglutinins in significant titers. It is probable that a number of the infections in this group were caused by organisms other than the meningococcus. Twenty-three and three

\footnotetext{
2 We are indebted to Dr. Erwin Neter of the Children's Hospital, Buffalo, N. Y., for supplying us with serums and the complete clinical resumés on more than 200 cases included in this study.
} 
TABLE I

Results of meningococcus agglutinin content tests on individuals tested from 1942-1952, New York City

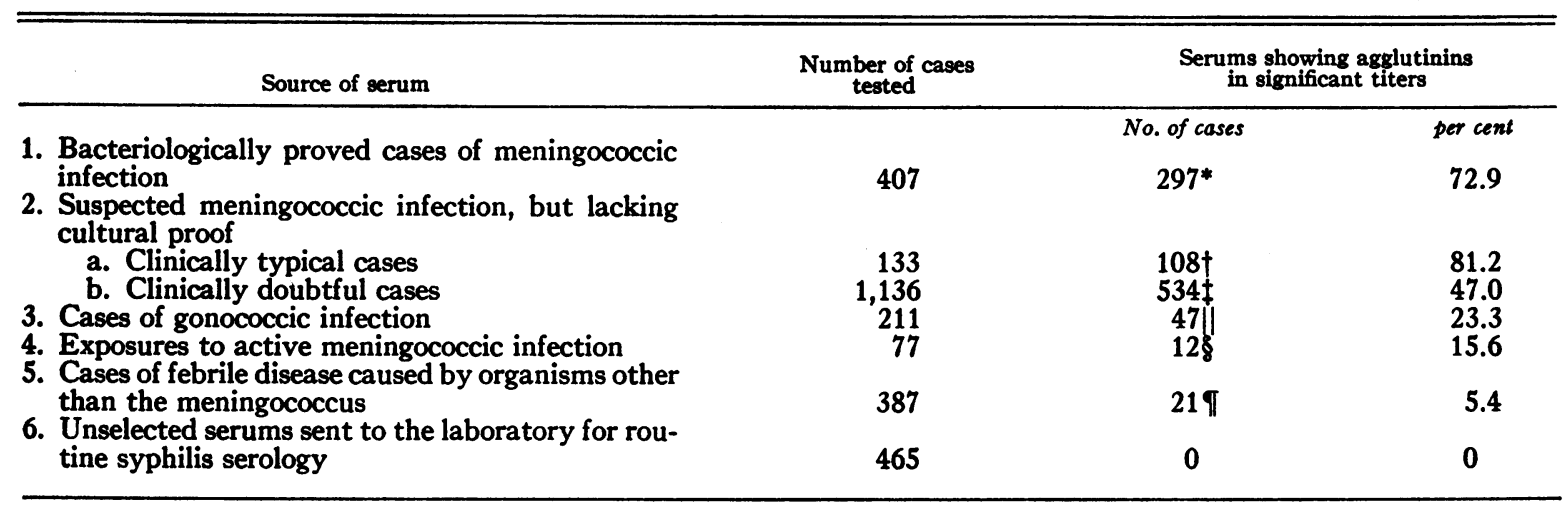

* 228 cases showed agglutinins for Group 1; 10 cases for Group 2; 13 cases for Group 2-a; 38 cases for Groups 1 and 2-a; and 8 cases for Groups 1, 2, and 2-a.

$\dagger 87$ cases showed agglutinins for Group 1; 2 cases for Group 2; 7 cases for Group 2-a; 10 cases for Groups 1 and 2-a; and 2 cases for Groups 1, 2, and 2-a.

¥ 396 cases showed agglutinins for Group 1; 6 cases for Group 2; 54 cases for Group 2-a; 61 cases for Groups 1 and 2-a ; 7 cases for Groups 1,2 and 2-a; 7 cases for Groups 1 and 2; and 3 cases for Groups 2 and 2-a.

\|l 42 cases showed agglutinins for Group $1 ; 3$ cases for Group 2-a; and 2 cases for Groups 1 and 2-a.

8 instances showed agglutinins for Group 1; 4 for Group 2-a; and one for Groups 1 and 2-a.

II 19 cases showed agglutinins for Group 1 ; and 2 cases for Groups 1 and 2-a.

tenths per cent of 211 instances of gonococcic infection also showed agglutinins in significant titers, as well as 15.6 per cent of the 77 individuals exposed to active meningococcic infection. On the other hand, only 5.4 per cent of 387 cases of febrile disease caused by organisms other than the meningococcus showed meningococcic agglutinins. The positive findings were noticed in the following disease states: influenzal meningitis ( 5 cases), pneumococcic meningitis ( 4 cases), tuberculous meningitis ( 2 cases), and in luetic meningitis, sympathic meningitis with brain tumor, three different forms of encephalitis, poliomyelitis, Rocky Mountain Spotted Fever, measles, staphylococcic sepsis, and erythema nodosum (one case each). One can only speculate on the significance of these few positive results. It is possible that the apparent false-positives may be contacts to active meningococcic infection or harbor meningococci which indicate latent infection not the basic cause of the current illness. Agglutinins for Group 1 meningococci were the predominant type encountered in each group. Group 2-a agglutinins alone or in combination with Group 1 were observed in from 10 to 40 per cent of the cases in each group. Agglutinins for Group 2, however, were found only in 10 per cent of the bacteriologically proved or suspected cases of meningococcic infection. In contrast to these findings, no agglutinins in titers over 1 to 100 were observed in any of the 465 control serums sent to the laboratory for routine syphilis serology.

As the investigation progressed it became apparent that for optimum results successive specimens must be tested during the various phases of the disease. It will be noted that when such serial tests were made on three or more specimens in either the group of bacteriologically proved cases or in the group of clinically typical cases lacking such proof, the magnitude of positive results exceeded 95 per cent (Table II). In the same two groups positive findings were observed in 84 per cent of the cases when two specimens were tested, and could be expected only in approximately 60 per cent of the cases when a single serum was available. While there was a slight rise in the per cent of positive findings in the group of individuals suffering from febrile diseases caused by organisms other than the meningococcus, the number of instances in which three or more specimens were available was comparatively small and cannot be considered statistically significant. In one of these instances the case may be considered a contact since it was in a crib next to a meningococcic meningitis patient. Another subject yielded negative serums until the 15 th day, followed by a gradual increase in titer from the 17 th 
TABLE II

Relationship of the appearance of significant titers to the number of successive specimens tested at intervals of from three to seven days

\begin{tabular}{|c|c|c|c|c|}
\hline \multirow{2}{*}{ 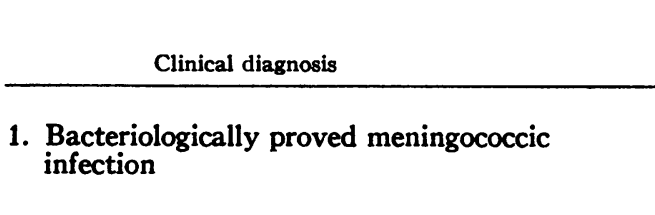 } & \multirow{2}{*}{$\begin{array}{l}\begin{array}{c}\text { Number of } \\
\text { specimens tested }\end{array} \\
1 \\
2 \\
3 \text { or more }\end{array}$} & \multirow{2}{*}{$\begin{array}{r}\begin{array}{r}\text { Number } \\
\text { of cases }\end{array} \\
212 \\
102 \\
93\end{array}$} & \multicolumn{2}{|c|}{$\begin{array}{l}\text { Type specific meningococcic } \\
\text { agglutinins observed in titer } \\
\text { over } 1 / 100\end{array}$} \\
\hline & & & $\begin{array}{c}\text { No. of cases } \\
120 \\
85 \\
92\end{array}$ & $\begin{array}{c}\text { per cent } \\
56.6 \\
83.3 \\
98.9\end{array}$ \\
\hline \multicolumn{5}{|l|}{ 2. Suspected meningococcic infection } \\
\hline a. Clinically typical & $\begin{array}{l}1 \\
2 \\
3 \text { or more }\end{array}$ & $\begin{array}{l}50 \\
37 \\
46\end{array}$ & $\begin{array}{l}32 \\
32 \\
44\end{array}$ & $\begin{array}{l}64.0 \\
86.0 \\
95.7\end{array}$ \\
\hline b. Clinically doubtful & 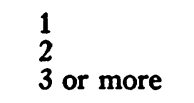 & $\begin{array}{r}815 \\
222 \\
99\end{array}$ & $\begin{array}{r}316 \\
145 \\
75\end{array}$ & $\begin{array}{l}38.8 \\
64.4 \\
75.7\end{array}$ \\
\hline $\begin{array}{l}\text { 3. Febrile diseases caused by organisms other than } \\
\text { the meningococcus }\end{array}$ & $\begin{array}{l}1 \\
2 \\
3 \text { or more }\end{array}$ & $\begin{array}{r}283 \\
72 \\
32\end{array}$ & $\begin{array}{r}13 \\
4 \\
4\end{array}$ & $\begin{array}{r}4.5 \\
5.5 \\
12.5\end{array}$ \\
\hline
\end{tabular}

to the 19th day. In the third case, the first test was made 78 days after the onset of illness.

The practical application of the meningococcus agglutination test and the individual variation which occurred can best be illustrated by present- ing protocols of a number of clinically typical cases without bacteriological proof (Table III).

Agglutinins corresponded in type with the infected organisms in every case where the organism was isolated and typed. This fact as well as the

TABLE III

Protocols of individual cases of clinically typical meningococcic infection lacking bacteriological proof

\begin{tabular}{|c|c|c|c|c|c|c|}
\hline \multirow{2}{*}{$\begin{array}{c}\text { Case } \\
\text { No. } \\
1\end{array}$} & Clinical summary & Laboratory findings & $\begin{array}{l}\text { Days } \\
\text { after } \\
\text { onset }\end{array}$ & \multicolumn{3}{|c|}{$\begin{array}{c}\text { Agglutinin titer } \\
\text { 1: }\end{array}$} \\
\hline & $\begin{array}{l}\text { History: White } 9 \text { aged } 18 \text { years, admitted } \\
\text { Jan. 10, 1947, sudden onset Jan. 8, head- } \\
\text { ache, vomiting, semi-stupor, delirium. Temp. } \\
104^{\circ} \\
\text { Examination: Rigid neck, Brudzinski +, } \\
\text { Kernig + } \\
\text { Clinical impression: Meningococcic } \\
\text { meningitis } \\
\text { Treatment: Sulfadiazine } \\
\text { Outcome: Recovered }\end{array}$ & $\begin{array}{l}\text { Spinal fluid: } \\
\text { Protein } 710 \mathrm{mg} . \% \\
\text { Sugar } 0 \mathrm{mg} \% \\
\text { Large no. polys. } \\
\text { Smear-negative } \\
\text { Culture-no growth }\end{array}$ & $\begin{array}{l}2 \\
5 \\
7\end{array}$ & $\begin{array}{r}400 \\
800 \\
1,600\end{array}$ & $\begin{array}{l}0 \\
0 \\
0\end{array}$ & $\begin{array}{l}0 \\
0 \\
0\end{array}$ \\
\hline 2 & $\begin{array}{l}\text { History: White } \sigma^{\top} \text { aged } 4 \text { years, admitted } \\
\text { Jan. 1, 1948, sudden onset Dec. } 31 \text {, circulatory } \\
\text { collapse that improved with stimulation. } \\
\text { Temp. } 105^{\circ} \\
\text { Examination: Rigid neck, Brudzinski t, } \\
\text { Kernig +, typical rash } \\
\text { Clinical impression: Meningococcic } \\
\text { meningitis } \\
\text { Treatment: Sulfadiazine and penicillin } \\
\text { Outcome: Recovered }\end{array}$ & $\begin{array}{l}\text { Spinal fluid: } \\
\text { Protein } 300 \mathrm{mg} . \% \\
\text { Sugar } 10 \mathrm{mg} . \% \\
\text { Large no. polys. } \\
\text { Smear-negative } \\
\text { Culture-no growth }\end{array}$ & $\begin{array}{r}2 \\
5 \\
9 \\
12\end{array}$ & $\begin{array}{l}0 \\
0 \\
0 \\
0\end{array}$ & $\begin{array}{l}0 \\
0 \\
0 \\
0\end{array}$ & $\begin{array}{r}0 \\
100 \\
800 \\
1,600\end{array}$ \\
\hline 3 & $\begin{array}{l}\text { History: Colored } 0^{7} \text { aged } 3 \text { weeks, admitted } \\
\text { July 19, 1945, sudden onset July 18, irritable, } \\
\text { convulsions, crying, rash. Temp. 103 } \\
\text { Examination: Typical meningococcic rash } \\
\text { Clinical impression: Meningococcemia } \\
\text { Treatment: Sulfadiazine } \\
\text { Outcome: Recovered }\end{array}$ & $\begin{array}{l}\text { Blood culture: } \\
\text { Negative }\end{array}$ & $\begin{array}{l}7 \\
19,26 \\
36,41 \\
55 \\
57 \\
66\end{array}$ & $\begin{array}{r}0 \\
1,600 \\
400 \\
1,600 \\
800 \\
400\end{array}$ & $\begin{array}{l}\mathbf{0} \\
\mathbf{0} \\
\mathbf{0} \\
\mathbf{0} \\
\mathbf{0} \\
\mathbf{0}\end{array}$ & $\begin{array}{l}\mathbf{0} \\
\mathbf{0} \\
\mathbf{0} \\
\mathbf{0} \\
\mathbf{0} \\
\mathbf{0}\end{array}$ \\
\hline
\end{tabular}


TABLE IV

Protocols on three brothers admitted to the hospital with symptomatology of acute meningococcemia

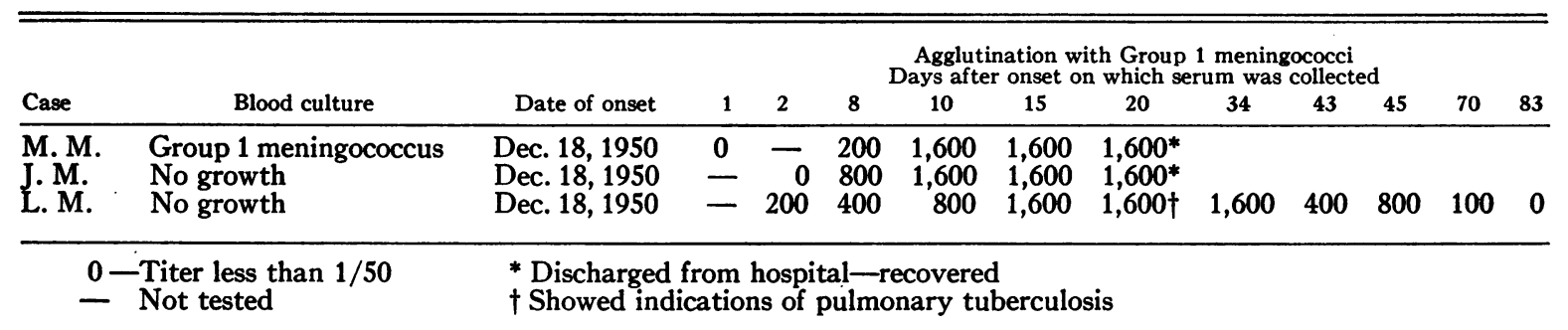

high percentage of positive findings observed in the group of clinically typical cases lacking bacteriological proof suggested that the test could be used in tracing the epidemiology of an outbreak. The effectiveness of this method was illustrated by the case of three brothers admitted to the hospital with symptoms of acute meningococcemia on December 10, 1950 (Table IV). A Group 1 meningococcus was recovered from only one of these patients. Serums were collected from each patient at regular intervals. By the eighth day one showed a titer of 1 to 200 for Group 1 meningococci, the second a titer of 1 to 400 and the third a titer of 1 to 800 . All reached a maximum titer of 1 to 1,600 by the 15 th day. Final serums were received from two of the brothers (M. M. and J. M.) on the 20th day. The titers were still 1 to 1,600 . The third brother (L. M.) revealed the presence of pulmonary tuberculosis and remained at the hospital. Serums continued to be sent at regular intervals. A titer of 1 to 1,600 persisted until the 34th day, then dropped gradually to 1 to 100 by the 70th day, and was completely negative on the 83rd day.

\section{DISCUSSION}

This study demonstrates clearly that the results of the meningococcus agglutination test have been consistent over a ten year period, and the test was shown to be of as much value in sporadic cases as it was in those occurring during outbreak periods. The scope of usefulness of the test includes the following: 1) a diagnostic procedure in cases of clinically typical meningococcic infection but lacking bacteriological proof ; 2) a method of typing the infecting organisms in instances where monovalent typing serum is unavailable; and 3) tracing the epidemiology of an outbreak.
When used as a diagnostic procedure, serial tests covering the various phases of the disease were found to be of the utmost importance and little or no reliance could be placed on the results obtained from a single specimen. As shown above, both bacteriologically proved and clinically typical cases lacking such proof yielded significant titers in 95 per cent of the instances when tested several times at appropriate intervals. It was also noted in one of our earlier studies (2) that serums collected early in the acute phase or late in convalescence were often negative. These observations serve, in large measure, to explain the conflicting results obtained by other investigators (3-5).

The use of patients' serum with antigens of known specificity to type the infecting agent is becoming more important due to the discontinuance of the commercial production of typing serums. Furthermore, it may not always be practical to send cultures to typing centers, both because of the hazards involved in the transportation of meningococci and because of the need for isolating the organisms in pure culture for that purpose.

The chief value of tracing the epidemiology of an outbreak by means of the agglutination test is that serums may be withdrawn from comparatively large numbers of individuals and stored in the refrigerator or frozen for future study. This is by far less laborious than isolating the infecting organisms from contacts which involves the availability of special culture media and a large staff, trained in the isolation of these rather fastidious organisms.

For proper interpretation of the test as a diagnostic aid, the results of the agglutination titers must be correlated with the clinical picture. In some instances the presence of significant titers 
may be indicative of a latent meningococcic infection which may not necessarily be the cause of the patient's present illness. It is possible that this type of infection accounts for the significant titers observed in approximately 16 per cent of exposures to active meningococcic disease and for the apparent false-positive findings noted in a small percentage of febrile diseases caused by organisms other than the meningococcus. This concept is in accord with Hedrich's recent report (6) in which the first clinical stage of meningococcic disease is described as an asymptomatic nasopharyngeal infection. Some of the false-positive findings may also be due to anamnestic reactions.

This study did not include carriers. But the observations of Rake (7), Miller (3), and Logan (5) indicate that meningococcal agglutinins in low titers may be found in the serum of these individuals. The expectation that a random sampling of serums would show agglutinins in significant titers in a small percentage of instances, and reflect to some degree the carrier frequency, was not borne out, since none of 465 serums sent to the laboratory for syphilis serology yielded a positive agglutination titer.

It was noted in this study that meningococcic agglutinins in significant titers were demonstrated in approximately 23 per cent of our subjects who were infected with other members of the Neisserian group. It is of interest to note that in these subjects agglutinins for Groups 1 and 2-a were observed but none for Group 2. However, the titers in these instances were relatively low and successive specimens were available in only five out of 211 cases. Even in these five individuals, serums were collected at intervals of a month or more, and the progressive changes observed in typical cases of meningococcic infection could not be demonstrated. This aspect of the problem merits further study.

\section{SUMMARY AND CONCLUSIONS}

The results of these studies are in agreement with our previous observations. The meningococcus agglutination test has definite value in the establishment of the clinical diagnosis of meningococcic infection in instances where other laboratory methods are inadequate. This applies to sporadic cases as well as to those occurring during outbreaks. In the absence of clinical evidence, it is not possible to distinguish between active and latent infection. The test may be useful in epidemiological studies and in typing the infecting organisms. The importance of performing several tests to demonstrate the change of agglutinin titer cannot be over-emphasized.

\section{ACKNOWLEDGMENTS}

We are grateful to Miss Rita Kohler, Mrs. Ruth Smith and Mrs. Evelyn Sugar for technical assistance.

\section{REFERENCES}

1. Falk, C. R., and Appelbaum, E., Type specific meningoococcic agglutinins in human serum: I. Description of Method. Proc. Soc. Exper. Biol. \& Med., 1944, 57, 341.

2. Falk, C. R., and Appelbaum, E., Type specific meningococcic agglutinins: II. The relationship of the titers to the course of the disease. J. Clin. Invest., 1945, 24, 742 .

3. Miller, C. P., A note on the agglutination of the meningococcus. Yale J. Biol. \& Med., 1944, 16, 519.

4. Mayer, R. L., and Dowling, H. F., The determination of meningococcic antibodies by a centrifuge-agglutination test. J. Immunol., 1945, 51, 349.

5. Logan, W. R., Meningoccemia : Part III. Bacteriology, serology and aetiology, Edinburgh Med. J., 1946, 53, 235.

6. Hedrick, A. W., Recent trends in meningococcal disease. Pub. Health Rep., 1952, 67, 411.

7. Rake, G., Studies on meningococcus infection. VII. The study of an isolated epidemic. J. Exper. Med., $1935,61,545$. 